$\S=-1$

\title{
Studying the Role of Brand Community in Designing and Developing a New Product (Case Study: Cosmetics)
}

\author{
Farshad Alidaie
}

Department of Management, Semnan Branch, Islamic Azad University, Semnan, IRAN

\begin{abstract}
The purpose of this study was to study the role of the brand community in the design and development of a new product (case study: cosmetics). The statistical society is the customers of Arian Kimia Tak Co. one of the successful companies in cosmetics industry in Iran. A questionnaire was used to collect data and 384 questionnaires were distributed among the customers of Arian Kimia Tak Co. and the required data were collected. In order to determine the sample size, the simplest method, Cochran formula, was used when the size of the community was unclear; the sample size was 384 . The results of the data analysis show that there is a significant relationship among the identity of the brand community, the commitment to the brand community, attachment to the brand community and the similarity of the brand community with the design and development of a new product
\end{abstract}

Keywords: : Brand Community, Brand Identity, Brand Commitment, Brand Attachment, New Product Development.

\section{Introduction}

Most progressing companies around the world are fully aware of the fact that the most important factor which makes them superior to the global competition, is the ability to continue designing and delivering a new product to the market faster and more efficient than the other competitors. Today, the organizational survival depends on the tendency towards the new products and the use of methods to create new successful products. With the advancement of technology, more competitiveness of the organizations, the emergence of new developed science and equipment, the fundamental changes in the needs and desires of customers, the manufacturing of new products has faced with new challenges [1].

The importance of developing a new product plays an important role in the global competition market as well as maintaining the current customers of the organization. In fact, the customers are constantly faced with the changing tastes and new mindsets about lifestyle and in the meantime, the design of new products matched with the needs of customers and their satisfaction has the great importance [2].

In many industries, the ability to quickly, efficiently and effectively develop a new product is the most important factor in its success. Despite the high attention paid to developing new products, the rate of failure of new product development projects is still high. According to many estimates, more than $95 \%$ of all new product development projects cannot achieve an economic output. Hence, a significant amount of researches is focused on how more effective and efficient the new product development process is [3]. In today's dynamic business world, companies are severely seeking the competitive advantage so that they can surpass their competitors. Undoubtedly, the development of a new product is an introduction to this stage. There is a lot of pressure to reduce the cost and time of product development due to the shorter product life cycle. The faster delivery time for new products can lead to a higher volume of sales. Therefore, it is very important that the product development processes be simplified to speed up the development projects. New product development is a process in which a new product or service is distributed in market. The success of this process can be measured by defining indices indicating the rate of success or failure [[.

On the other hand, the brand plays a role as an important feature of the product and organization in the domestic and global competition market and the supply of a new product in the market will be accompanied by a brand name.

Branding community has become very important given the importance of marketing planning process and paying attention to brand equity and in the last years has become one of the most encouraging developments in relational marketing. The brand community is a powerful phenomenon that has emerged all over the world and has brought many benefits to the companies.

Ariane Kimia Tak Co., the case study, is one of the leading companies in the cosmetics and healthcare industry that develops the brand MAY and produces the products of this brand. according to the company's report in 1995, the company has provided over 40 new products; for this, the study in this section is one of the company's priorities [5]. Further research has shown that some of the products presented in the market have been successful and some of them have been somewhat unsuccessful. Success and failure with the regard to the sales budget and stock inventory and the amount of sales and profitability of the product etc. of these products have been identified. Therefore, this issue should be addressed as a serious issue in the design and production of new products, especially in the cosmetics industry. In this research, we study the role of brand community in designing and developing a new product in the cosmetics industry for new products manufactured in the year 2015 .

\section{Literature Review}

Amirshahi [6] in a study entitled " The Effect of Consumer Innovation on Purchasing Decision Styles" says that the innovation and new product supply have important roles in the growth and profit- 
ability of the companies and marketing managers are targeting innovative consumers to succeed in selling and marketing their new products. Findings of the research show that cognitive innovativeness has the direct relationship with the purchasing decision style of "sensitive to excellent and perfect quality" and emotional renewal with the purchasing decision style of "brand-sensitive", "new and fashionable" and "for fun".

Amirmaniyan and Asgharizadeh [4], in a research entitled "The role of knowledge management in the performance of the new product development process, research on SME companies in the software industry in Yazd province" studied the role of knowledge management and key factors of success in the performance of the new software products development, based on the study of software companies in Yazd Province. The results show that there is a significant relationship between success in the performance of the new product development process with key factors of success and knowledge management. There is also a significant relationship between the key factors of success and knowledge management. did a research entitled "The Impact of Brand Community on the Social Networks on the Brand Customers' Trust and Loyalty". In this research, a questionnaire was distributed among all students of Allameh Tabataba'i University to collect the data. A random stratified random sampling method was used and 375 students answered it. The research results indicate that the brand community affects the customer relationship with product, customer relationship with brand, customer relationship with company, but does not affect the customer relationship with the other users.

The relationship between the customer and product performance has been positive and significant in the market. But the relationship between the supply chain and product design by the moderator variable is negative and not significant.

In the research, studied the relationship between the stages of Takeuchi Knowledge Spiral Model including: internalization, outsourcing, socialization, and combination with four stages of the process of new product development including the planning, development, marketing and commercialization. On this basis, in the first stage, it is occurred the socialization development, in the second stage, the outsourcing, in the third stage, the combination and in the fourth stage, the internalization of knowledge occur [6]. In an article, studied the relationship between the use of knowledge management tools and new product performance. According to this study, the collaboration experience and the size of the organization and the naturalness of the use of information and communication technology have a positive effect on the use and trust of knowledge management tools and the use of knowledge management tools leads to increasing the market supply and new product performance and also increasing the financial performance(7)

\section{Methodology}

The method of this study is practical because its expected results can be applied by the managers of the manufacturing companies, in particular the company being studied, in the process of promoting their insight into the brand community. Also, this research is a correlation type in terms of method. The statistical population of the study was all the customers of Arian Kimia Tak Co. one of the successful companies in the field of cosmetic production inside. Sampling method was simple random method and library and field methods were used for collecting the data. A questionnaire was used to collect data and 384 questionnaires were distributed among the clients of Arian Kimia Tak Company and data requirements were collected. After collecting the data from the questionnaire and statistical analysis, the hypotheses have been tested. In order to determine the sample size, the simplest method, using Cochran formula was used when the size of the community was unclear, and the sample size was 384 .

\section{Hypotheses}

1- There is a significant and direct relationship between the identification of the brand community and the design and development of the new product.

2- There is a significant relationship between commitment to the brand community and the design and development of the new product.

3- There is a significant relationship between attachment to the brand community and the design and development of the new product.

4- There is a significant relationship between the similarity of the brand community and the design and development of the new product

\section{Results and discussion}

In this section, the test results of the research hypotheses are examined. To investigate the data, the first step was to test the normality of the data and the results of Kolmogorov-Smirnov test showed that the data were normal distributed. The parametric tests are used to test the hypotheses. In this research, Pearson correlation test and multiple regression analysis have been used. The test results are presented below.

The results of the correlation test are presented in Table (5-1). The correlation is used due to the fact that the hypotheses are the relational type.

Table 5-1- Summary of the Results of the Research Hypotheses Test (Source: Research Findings)

\begin{tabular}{|l|l|l|l|l|}
\hline $\begin{array}{l}\text { Independent } \\
\text { variable }\end{array}$ & $\begin{array}{l}\text { Dependent } \\
\text { variable }\end{array}$ & $\begin{array}{l}\text { Correlation } \\
\text { coefficient }\end{array}$ & $\begin{array}{l}\text { Significance } \\
\text { level }\end{array}$ & Test result \\
\hline $\begin{array}{l}\text { Identification } \\
\text { of the brand } \\
\text { community }\end{array}$ & 0.602 & 0.000 & $\begin{array}{l}\text { hypothesis } \\
\text { is con- } \\
\text { firmed }\end{array}$ \\
\hline $\begin{array}{l}\text { Commitment } \\
\text { to the brand } \\
\text { community }\end{array}$ & $\begin{array}{l}\text { New product } \\
\text { design and } \\
\text { development }\end{array}$ & 0.426 & 0.001 & $\begin{array}{l}\text { hypothesis } \\
\text { is con- } \\
\text { firmed }\end{array}$ \\
\hline $\begin{array}{l}\text { Attachment } \\
\text { to the brand } \\
\text { community }\end{array}$ & 0.512 & 0.000 & $\begin{array}{l}\text { hypothesis } \\
\text { is con- } \\
\text { firmed }\end{array}$ \\
\hline $\begin{array}{l}\text { similarity of } \\
\text { the brand } \\
\text { community }\end{array}$ & & 0.376 & 0.023 & $\begin{array}{l}\text { hypothesis } \\
\text { is con- } \\
\text { firmed }\end{array}$ \\
\hline
\end{tabular}

\section{The First Hypothesis}

In the case of the first hypothesis, the results show that with $95 \%$ confidence and at an error level less than 0.05 , there is a significant relationship between independent variables and dependent variable. This means that the identification and brand identity variable effect on the design and development of the new product in Kimia Tak Co. On the other hand, the value of this relationship, which is equal to 602 , implies a strong correlation between two variables of identification of the brand community with the designing and developing a new product. Therefore, it can be concluded that there is a significant positive correlation between identification of the brand community with the design and development of the new product; then, the hypothesis zero is rejected and the hypothesis one is confirmed.

\section{The Second Hypothesis}

In the case of the first hypothesis, the results show that with $95 \%$ confidence and at an error level less than 0.05 , there is a significant relationship between independent variables and dependent variable. This means that the commitment to the brand community variable effect on the design and development of the new product in Kimia Tak Co. On the other hand, the value of this relationship, which is equal to 0.426 , implies a strong correlation between two variables of the commitment to the brand community variable with the designing and developing a new product. Therefore, it can be concluded that there is a significant positive correlation between the commitment to the brand community variable with 
the design and development of the new product; then, the hypothesis zero is rejected and the hypothesis one is confirmed.

\section{The Third Hypothesis}

In the case of the first hypothesis, the results show that with $95 \%$ confidence and at an error level less than 0.05 , there is a significant relationship between independent variables and dependent variable. This means that the attachment to the brand community variable effect on the design and development of the new product in Kimia Tak Co. On the other hand, the value of this relationship, which is equal to 0.512 , implies a strong correlation between two variables of the attachment to the brand community variable with the designing and developing a new product. Therefore, it can be concluded that there is a significant positive correlation between the attachment to the brand community variable with the design and development of the new product; then, the hypothesis zero is rejected and the hypothesis one is confirmed.

\section{Conclusion}

The research interest in brand community originates from the fact that the brand community help companies attract and empower the individual customers, thereby establish the long-term relationships. These long-term relationships with the customers, make the companies more competitive, and as a result, their marketing effectiveness increases significantly. However, the studies on the brand community have not had the ability to deal with the whole circle, from forming the relationships with customers to improve the marketing efficiency. Instead, the research emphasizes on a variety of fields such as the impact of Brand Communities on brand loyalty, attitudes based on the level of agreement between the brand community and the self-concept and the relationship between community brand activities and brand community loyalty. The reason for this kind of research focus is that the brand community is often defined in terms of relationships in which customers are located in, including relationship between customer and brand, between customer and company, between customer and product used and among the customers followed[8].

Attention to brand is critical to the development of a new product, and with introducing a product brand to the customers, new products can be produced and expect its success. Therefore, the product development and brand issues are interdependent and the present research was also conducted in order to investigate the impact of brand community on the design and development of new products. The results of the research show that there is a significant and direct relationship between identification of the brand community and the design and development of the new product. In the other words, the greater the identification of the brand community, the new product design can be improved.

On the other hand, the result of the research showed that there is a significant relationship between the commitment to the brand community and the design and development of a new product. Whatever the direction of this connection is direct, the more commitment to the brand community grows, the better the new product design is improved. In the other section of the study, the result of the third hypothesis showed that there is a significant relationship between the attachment to the brand community and the design and development of a new product. In the other words, a great deal of attachment for the brand community affects the design and development of a new product. Finally, the result of the fourth hypothesis of the research states that there is a significant relationship between the similarity of the brand community and the design and development of a new product[9].

\section{References}

[1].Sarmadi S. et al. (2009), "Identifying and Ranking Key Effective Factors in New Product Development in SAIPA Automotive Group with the AHP Approach" Marketing Management Magazine No. 8: 114-18

\section{The Fourth Hypothesis}

In the case of the first hypothesis, the results show that with $95 \%$ confidence and at an error level less than 0.05 , there is a significant relationship between independent variables and dependent variable. This means that the similarity of the brand community variable effect on the design and development of the new product in Kimia Tak Co. On the other hand, the value of this relationship, which is equal to 0.512 , implies a strong correlation between two variables of the similarity of the brand community variable with the designing and developing a new product. Therefore, it can be concluded that there is a significant positive correlation between the similarity of the brand community variable with the design and development of the new product; then, the hypothesis zero is rejected and the hypothesis one is confirmed..

[2].Dehnavi (2012) "Investigating the factors impacting the position of new product development in the textile industry", The Third Conferences of Textile and Apparel Engineering, Yazd, May 2012

[3].Ismailpour \& Jabari (2010), "Investigating the Process of New Product Development from Idea to Supply to the Market" , Industrial management ,12 (7): 77-84

[4].Amirmaniyan \& Asgharizadeh (2011), "The role of knowledge management in the performance of the new product development process, research on SMEs in the software industry in Yazd province" Iran journal of knowledge management , 7(2):22-35

[5].Eghbali A. Nayebzadeh S. (2014), Brand and Online Brand Community, International Conference on Economics, Accounting, Management and Social Sciences, Poland

[6].Amirshahi M.A. Heydarzadeh K. Dabestani F. (2011), "The Effect of Consumer Innovation on Purchasing Decision-Making Styles". Two Journal of Research on New Marketing Research, First Year, No 3: 55-63

[7].Cowart, K O, Fox G L \& Wilson A E 2008, "A Structural Look at Consumer Innovativeness and Self-Congruence inNew Produ ct Purchases", Psychology \& Marketing, Vol. 25, No. 12, pp.11111130.

[8].Boush, D.M. \& Loken B. A. (1991)."Process-tracing study of brand extension evaluation", Journal of Marketing Research, 28 (1), pp. 16-28

[9].Vandecasteele, B 2010, "Innovative Consumers: Who, Why, and How to Target?", A Doctor Dissertation, Ghent University. 